\title{
Conventions, Money Creation and Public Debt to Face the Covid-19 Crisis and its Aftermath: A Post-Keynesian View
}

\author{
Convenções e Emissão de Moeda e de Dívida Pública \\ para Combater a Crise Econômica da Covid-19: \\ uma perspectiva Pós-Keynesiana
}

\author{
MARCO FLÁVIO DA CUNHA RESENDE* \\ FÁBIO HENRIQUE BITTES TERRA** \\ FERNANDO FERRARI FILHO ***
}

RESUMO: O objetivo deste artigo é, por um lado, analisar, com base nas ideias de Keynes, a relevância da emissão de moeda e de dívida pública para mitigar a crise econômica da Covid-19 e, por outro lado, analisar o papel das convenções neste contexto.

PALAVRAS-CHAVE: Crise da Covid-19; Keynes; política econômica; emissão de moeda; dívida pública.

ABSTRACT: The aim of this article is, on the one hand, to analyze, based on Keynes's ideas, the relevance of money creation and public debt to mitigate the Covid-19 economic crisis, and, on the other hand, it analyses the role of conventions in this context.

KEYWORDS: Covid-19 crisis; Keynes; economic policies; money creation; public debt. JEL Classification: E12; E30; E50; E60.

\footnotetext{
* Associate Professor at Federal University of Minas Gerais and Researcher at National Council of Scientific and Technological Development (CNPq), Brazil. E-mail: resende@cedeplar.ufmg.br. Orcid: https://orcid.org/0000-0003-2069-2983.

** Associate Professor at Federal University of ABC and at the Economics Graduate Programme of the Federal University of Uberlandia, and CNPq Researcher, Brazil. E-mail: fhbterra@gmail.com. Orcid: https://orcid.org/0000-0002-2747-7744.

*** Retired Professor of Economics at Federal University of Rio Grande do Sul and Researcher at National Council of Scientific and Technological Development (CNPq), Brazil, and Visiting Professor at Washington and Lee University, United States. E-mail: ferrari@ufrgs.br. Orcid: /https//0000-0001-5600-7058. Submitted: 3/June/2020; Approved: 15/June/2020.
} 


\section{INTRODUCTION}

The Covid-19 pandemic produced a collapse in economic life. It globally caused a huge recession and high unemployment, increased debts of companies and families, and the liquidity preference of the financial system. In this context, countercyclical economic policies became the only possibility of rescuing the economies from recession.

According to Keynesian theory, declines in economic activity or even deep slumps are an ever-present possibility whenever markets are left alone. This is a consequence of the fundamental uncertainty that prevails in the economies. It entails a role for government not only in times of economic recession, but also in times of growth, since public policies are able to prevent economic cycles of boom or bust. Thus, Keynes proposed that State and private sector should cooperate, as only the former can send signals to private agents and lead the economy towards a promising future path.

Since the beginning of 2020, governments and Central Banks (CBs) have been adopting expansionary fiscal and monetary policies to mitigate the Covid-19 pandemic crisis. Governments have increased their debt levels, and in some cases the fiscal measures reached more than $10.0 \%$ of GDP (IMF 2020). CBs have adopted measures to stimulate liquidity in the financial system. Despite the fact that the fiscal and monetary measures differ among countries, in general they have increased the public debt-to-GDP ratio, reduced the base interest rate, and either adopted or deepened some kind of non-conventional monetary policy (IMF 2020; CouppeySoubeyran 2020; Botta et al. 2020).

Even though this policy arrangement has been undertaken by many countries to tackle the economic crisis, some authors argue, like Galí (2020), CouppeySoubeyran (2020) and Botta et al. (2020), that it is not enough. It would be needed even more aggressive fiscal and monetary policies. According to Galí (2020) and Couppey-Soubeyran (2020) money creation is important to provide a direct transfer of cash from CBs to households, companies and national treasuries. Botta et al. (2020) suggest a plan of emergency spending by eurozone governments:

"Governments should then finance their crisis response by issuing public bonds that the ECB [European Central Bank] directly purchases on the primary market (see De Grauwe, 2020) and subsequently writes off from its own balance sheet. In doing so, the ECB will de facto make a transfer to the accounts of eurozone governments in order to provide them with the resources needed to tackle the current economic emergency (see Galì, 2020). This way, it will avert further increases in public debt stocks that could restrain governments' efforts to boost economic recovery." (Botta et al. 2020: 241)

The aim of this article is to explain, in John Maynard Keynes's views, the relevance of countercyclical fiscal and monetary policies to mitigate the Covid-19 
economic crisis. We recall that Keynes proposed his economic policies for a period as turbulent as nowadays: in between World War I and II, and mostly after the Great Depression of 1929. In view of that, we specifically debate the importance of money issuance as well as a more intense use of public debt to finance greater government spending to tackle the Covid-19 crisis.

In the Post-Keynesian literature, the Modern Monetary Theory (better known for its acronym, MMT) is known for proposing, based on the neochartalist approach of Lerner's (1943) functional finance, that governments have not gotten financial constraints to increase their deficit spending. It can always be financed by public debt and/or money creation. But what does Keynes have to say about these means of financing countercyclical economic policies? The contribution of this article is to report how Keynes would see these two means of financing government in moments such as the economic slump related to the Covid-19 crisis. Additionally, the article brings up the role of convention in times of radical uncertainty in strengthening the countercyclical policies effects, in the Post Keynesian perspective.

Besides this introduction, the article has four other sections. Section two presents Keynes's views about the role of government in guiding agents' expectations through the influence of public policies in forming conventions in a monetary economy of production. In the third section, Keynes's economic policy prescriptions are briefly presented. Section four evaluates the roles of money creation and public debt on backing economic policies to address the Covid-19 crisis. Section five concludes.

\section{STATE AND MARKET: A NEEDED COOPERATION}

Keynes's contribution to understand the rational behavior under uncertainty and the formation of expectations was first developed in his A Treatise on Probability (Keynes 1921). Later on, he brought this approach to the The General Theory of Employment, Interest and Money (GT). ${ }^{1}$ Keynes (1921) argued that probability is not the outcome of statistical frequencies, but an objective-logic within a subjective rational relation between some premises and conclusions. ${ }^{2}$ Ac-

\footnotetext{
${ }^{1}$ Dequech (2000: 50) separate two concepts of uncertainty, fundamental uncertainty (or radical) and ambiguity. To him, "[s]ituations of ambiguity appear in his A Treatise on Probability [...] It is particularly in his later economic writings that Keynes refers to situations of fundamental uncertainty." Ambiguity refers to a kind of probabilistic uncertainty, in which the outcome of an event pertains to a close set, but the precise result cannot be known beforehand. Economic variables often bear ambiguity, because their value lies on a closed set of numbers. Still, it is impossible to anticipate the precise outcome. Fundamental uncertainty implies that some information does not exist at the decision time because the future is yet to be created. Finally, risk is a situation in which a person does not know which event will happen but unambiguously assigns a definite probability to each and every event. For more details, see Dequech (2000).

${ }^{2}$ Following Sen (2018: 6), “[a] major departure took place in Keynes's notion of probability by the 1930s when the famous mathematician-philosopher F. P. Ramsay (1931) questioned Keynes's information-theoretic (and objective) notion of probability in the Treatise. Ramsay was finally successful in changing Keynes's notion of probability to a subjective one $[. .$.$] the change finally led to the major$
} 
cording to Keynes (1921), knowledge is obtained by a process that starts with direct understanding. It results from human faculties that enable the ability of learning. Direct understanding builds the second step of knowledge, direct knowledge, that is, the set of premises upon which a conclusion will be reached. The conclusion is, in turn, called indirect knowledge by Keynes (1921), the endpoint of the process of obtaining knowledge.

Since premises (direct knowledge) are not complete due to the paucity of evidence (weight of argument), conjectures (or as Shackle (1979) called it, figments of imagination) are needed in the way of reaching conclusions. The figments of imagination are subjective so that conclusions depend on the set of conjectures subjectively taken by the decision-maker. This is the reason for two or more individuals achieve different outcomes from the same informational set. ${ }^{3}$

Still, how does one act based on his/her subjectively-reached conclusions? It depends on the confidence agents have on their own conclusions. Keynes (1921) called it degree of rational belief while in his GT, he deemed this creed as state of confidence. If agents are, for instance, entrepreneurs, their act of investing relying on their conclusions about future outcomes strongly lies on the confidence they have on their own conclusions. Their conclusions are their expectations of what shall happen in future. If they trust in their conclusions/expectations, they invest.

Thus, to Keynes, economic decisions are rational even though they are taken out of a set of incomplete information. ${ }^{4}$ In the Keynesian literature, market signals, such as price, wages, interest rates, industrial capacity use, among other indicators, inform about the present, but not about the future as it does not exist yet. Creativity of individuals and unpredictable structural changes are allowed. Therefore, there is a significant indeterminacy of the yet-to-be-created future.

The term uncertainty is widely used in the mainstream economics and has a different meaning compared the Keynesian view. To the mainstream economics, agents know, at the moment of their decisions, the universe of outcomes resulting from a given cause. They deal with calculable probabilities of a known universe of events. This idea supposes the presence of a unique, additive and fully reliable probability distribution which, in turn, is the result of the absence of both the possibility of agents' creativity and unpredictable structural changes (Dequech 2000). Thus,

alternative formulation of probability relations, which came up in his new book, The General Theory of Employment, Interest and Money (1936)".

${ }^{3}$ Even though the different outcomes achieved, all these individuals present a rational behavior under fundamental uncertainty. As Carvalho (2015: 47) states, "Keynesian agents make their choices as rationally as neoclassical agents. The difference is that, under uncertainty, agents choose among a subjectively-created list of outcomes while orthodox analysis postulates choice among objectivelydetermined lists of outcomes."

\footnotetext{
${ }^{4}$ Fundamental uncertainty does not refer to the problems of imperfect information, asymmetric information or market failures. According to Skidelsky (2010: 45), "[t]he present crisis [the Great Financial Crisis of 2008] shows that we are in a world of uncertainty, with the blind leading the blind. It is a crisis of symmetric ignorance, not asymmetric information.”
} 
the sample of past and present data is sufficient to allow individuals to access the future through calculable probabilities in a reliable way.

Moreover, decisions are crucial in the Post-Keynesian view. The very act of executing a plan may destroy the circumstances in which it was performed. Investments belong with this cruciality (Basili and Zapia 2006). Consequently, economic events related to the long run are usually not able to be replicated. Therefore, the conditions for calculating reliable probabilities do not exist. This disables agents from assuming rational expectations and maximizing behavior, making it impossible for automatic market forces to correct deviations of the economy from an optimal long-term equilibrium (Resende and Terra 2017).

As Keynes (2007: 98) states, "[s]ince our existing knowledge does not provide a sufficient basis for a calculated mathematical expectation", the decision-maker adopts a conventional behaviour. Conventions can be understood as a collective rule of behavior (Dequech 1999), or a mimetic behavior (Plihon 1995), and it is characterized as being "as interactive, as is confidence, individual and collective" (Davis 1997: xiii). Arestis et al. (2019) and Carvalho (2014) define convention as a shared belief that prevails over some time. Nevertheless, "decisions are not just a matter of expectations but also of how one trusts on what is expected. Hence, if conventions partly help forming expectations under uncertainty, the state of confidence of agents also depends on them" (Resende and Terra 2017: 248). So, conventions and expectations are related as the former helps molding the latter because agents understand conventions as a direct knowledge upon which form their conclusions in their rational process.

Although expectations are subjectively and independently formed by individuals, they tend to absorb conventions that are widely shared. What does promote this convergence? As Carvalho (2014: 247) argues, "the coexistence of a large number of independent decision units at a given point in time makes it necessary for each decision-maker to form expectations about the other's expectations." 5 Plans are made individually, but to be not frustrated they should be consistent with the prevailing conventions, if not expectations will hardly inspire confidence.

In monetary economies, insufficiency of effective demand is a frequent possibility. It leds to the two major problems of capitalism that Keynes (2007) highlighted: unemployment and the arbitrary and inequitable distribution of wealth and income. Due to the insufficiency of effective demand, Keynes (2007) claimed for a role for the State. It should act in a complementary way with the private sector. In his The End of Laissez-faire, Keynes (2010: 291) argued that the State should focus on "those functions which fall outside the sphere of the individual, to those decisions which are made by no one if the State does not make them." According to Keynes (2007), the role of government is to adjust, by means of macroeconomic policies, the propensity to consume and the inducement to invest:

\footnotetext{
${ }^{5}$ Translated to English by the authors.
} 
"The State will have to exercise a guiding influence on the propensity to consume partly through its scheme of taxation, partly by fixing the rate of interest $[\ldots]$ I conceive, therefore, that a somewhat comprehensive socialization of investment will prove the only means of securing an approximation to full employment; though this need not exclude all manner of compromises and of devices by which public authority will co-operate with private initiative." (Keynes 2007: 378) ${ }^{6}$

Macroeconomic policies affect the economy in both the demand side (for instance, economic and social policies change the aggregate demand of society) and the supply side (like taxes changing production costs). Also, conventions indirectly influence the economy, because they are accounted for in the investment decisionmaking process of entrepreneurs. ${ }^{7}$ Therefore, Arestis et al. (2019: 189) argue that "governments, which are the greatest social entity and have the power of creating and enforcing public policy, play a key role in forming conventions and consequently in establishing expectations."

Given that, as the economy bears fundamental uncertainty, then Keynes's theory of liquidity preference is valid, and money is demanded whenever unconfident expectations hover. However, if the absolute liquidity of money is required, goods which were produced to be purchased using that hoarded money are not bought. Insufficient effective demand takes place and some employment prior made is not needed anymore. To avoid and/or minimize that, State intervention is needed, i.e., there is a government role to be performed (Keynes 2010).

The Covid-19 pandemic was not expected. But it happened and the economic conditions changed dramatically, forcing social distancing, strongly reducing consumption, imposing losses, and disappointing expectations. The only source of reaction that was capable of being put in place to mitigate the countries' economic meltdown is the State, that is not asked for social distancing. They acted through economics and social policies, and undoubtedly showed that State intervention matters.

This State action amid the Covid-19 economic crisis has, of course, costs. This crisis is expected to be the worst the world ever had in times of peace so that the cost of the economic intervention of government is expensive. How to pay for the State countercyclical economic policies? The next section briefly describes the role of State economic intervention prescribed by Keynes and its connections with conventions.

\footnotetext{
${ }^{6}$ Ferrari-Filho and Conceição (2005) interpreted Keynes' 'socialization of investment' concerning the government role in providing institutional mechanisms to mitigate uncertainty and stimulate investment.

7 "Although Keynes has not explicitly formulated the connection between the government and conventions in his works [...] government's speeches, plans, policies and even circumstantial measures may be included in the set of 'existing facts which we can assume to be known more or less for certain', furnishing to the decision-makers more instances, and consequently confidence, in their expectations" (Resende and Terra 2017: 248-49).
} 


\section{KEYNESIAN ECONOMIC POLICIES}

To Keynes, the role of State was thus fundamental to ensuring macroeconomic stability and structural development. For that purpose, Keynesian macroeconomic policies should be coordinated. In that, (i) the fiscal policy is designed to expand effective demand and reduce social inequalities; (ii) monetary policy needs to manage the financial system yield curve; and (iii) the exchange rate policy regulates the financial and foreign-exchange markets in order to stabilise capital flows and exchange rates. In light of this, Keynesian economic policies aiming at restoring macroeconomic stability and promoting social development contemplate shortterm macroeconomic policies to address the economic crisis as well as structural measures to sustain economic growth over time and stimulate income and wealth distributions.

More specifically, fiscal policy should focus on expanding expenditures in both social programs and public investments to frame good conventions and boost the economic activity. Governments should seek fiscal responsibility, as Keynes (1980) recommended, ${ }^{8}$ although this should not be pursued as an end in itself, but on the criterion of countercyclical fiscal policy management. Additionally, fiscal responsibility contributes to avoid bad conventions. Fiscal policy needs to be expansionist in periods of crisis and recession, and neutral in times of economic growth. When the automatic stabilization of the fiscal policy fails and recession emerges, fiscal deficits are expected, though Keynes (1980: 353-4) deemed it a "desperate expedient". Nonetheless, if there are fiscal deficits for any reason, any further fiscal equilibrium should be chased gradually in time.

Monetary policy should be guided by an employment goal and not only to control inflation. For this purpose, discretionary monetary policy is indispensable. This means making monetary policy capable of undertaking financial measures such as debt management and asset purchase programs to largely administer the financial system yield curve. In both cases, central banks issue money to undertake these policies. They can occur in the primary and/or secondary private and public debt markets. If the CBs finance governments, they must act in the public debt primary market. The wide presence of CBs in the financial markets are important because if only market forces operate there, interest rates may go up whenever bearish behaviour occurs as well as market rates may present volatility prior, during, and after a crisis, disturbing the financial conditions of the economy. As Keynes (2007) stated, the rate of interest is a highly conventional phenomenon and the effectiveness of the monetary policy depends on the capacity of the monetary authority in framing conventions: "the long-term market-rate of interest will depend,

\footnotetext{
${ }^{8}$ In 1942, after analysing The Beveridge Report on the United Kingdom's social security budget, Keynes proposed introducing a budget split in 'ordinary' and 'capital'. He wrote, "the ordinary Budget should be balanced at all times [while] [...] the capital Budget [...] should fluctuate with the demand for employment” (Keynes 1980: 225).
} 
not only on the current policy of the monetary authority, but also on market expectations concerning its future policy" (Keynes, 2007, 203).

Also, regulation, mainly in the form of macro-prudential measures should be taken to mitigate financial risk and expand liquidity in the economy whenever it is necessary. As a consequence, it contributes to the emergency of optimistic conventions.

In terms of exchange rate, the central banks should administer the exchange rate seeking to keep the real effective exchange rate competitive, so any speculative actions on the foreign currency market should be contained. To achieve this goal, the central banks need to negotiate foreign currency to support exchange rate stability and counter disorderly conditions on the foreign exchange market. Thus, the exchange rate regime must be close to a managed floating exchange system. This preserves some flexibility in managing the short-term nominal exchange rate when needed, but at the same time maintain a stable and competitive real effective exchange rate, framing good conventions.

It is worth remembering that monetary and financial stability depends on exchange rate stability and vice-versa. Nowadays, given the highly developed and integrated capital markets, and the unprecedented liquidity in the international financial system, the exchange rate may increasingly act as a transmitter and amplifier of financial shocks, rather than as absorber of real shocks (Flassbeck 2018). Thus, multiple instruments are needed in order to stabilize the foreign exchange market, such as foreign exchange interventions, macroprudential policies and capital controls, which, in turn, add a degree of freedom for monetary policy. The use of traditional monetary policy adjustment through short-term interest rates might not be enough, and it is not suitable in the Keynesian view, to preserve exchange rate stability. ${ }^{9}$

Thinking about economic and structural measures, it is important to emphasise that the State's role in the economy must be redefined by rebuilding the coordination mechanisms that were dismantled during the neoliberal period, in the 1990s and 2000s. The State should once again exercise its function of being the coordinator and inducer of economic activity, so that the State has power to build a real Welfare State. It means that there is no way to expect the private sector to organize the offset of the crisis and an ulterior recovery. It is the private sector that suffers the most with the crisis. How can it, alone, make the recovery, even more in times of radical uncertainty and pessimistic conventions? It cannot. Economic policies are needed and issuing money and public debt are means of finance them, as we discuss in the next section, based on Keynes's perspective enrolled in the two sections above.

\footnotetext{
${ }^{9}$ These non-orthodoxy balance sheet policies are related to measures as asset purchases programs, auctions of non-deliverable forward to offer foreign exchange protection to investors without affecting the level of international reserves, swaps of long-term securities for short-term securities via auctions, foreign exchange reserves buffers and minimum loan-to-value ratios.
} 


\section{THE ROLE OF MONEY CREATION AND PUBLIC DEBT RISE AT THE COVID-19 ECONOMIC CRISIS}

\section{The economic impact of Covid-19 and the countercyclical economic measures}

Twelve years after the Great Financial Crisis of 2008, which was the second major crisis of capitalism, an even bigger one emerged in 2020 due to the COVID-19 pandemic. In the first months of 2020, worldwide the stock-markets deeply turmoiled, capital flighted from emerging markets, bank credit was reduced, long term government bonds yields plummeted with ten-year U.S. government bonds yields dipping below one percent for the first time ever, GDP growth rates fell, and unemployed rate dramatically increased.

The economies had a sudden and deep dive due to the peculiarity of the cause of the crisis, arising from a shock of both supply and demand originated by the pandemic (Botta et al. 2020). Therefore, the traditional countercyclical macroeconomic policies, though necessary, are not sufficient to rescue economic activity. They take time to make their whole effects on the economies, as they are slowed because of transmission failure problems caused by the crisis.

The emergency measures adopted by countries refers hitherto to both fiscal packages that rely on government spending to compensate for the revenue loss of households and companies and unconventional monetary policy. The latter includes direct cash transfers as well as monetary and financial measures like launching new asset purchase programs, temporarily slackening banks' capital requirements, public debt management, and easing bank refinancing conditions with $\mathrm{CB}$ credit facility actions (IMF 2020; Botta et al. 2020).

In face of a huge rise of people and firms' liquidity preference, CBs' interventions in primary and secondary markets are important to prevent financial asset deflation and reassure primary market investors, facilitating the conditions of granting finance in the financial markets, to households, companies and government. Nevertheless, money may not arrive in a sufficient amount in the real economy because of banks' credit rationing triggered by the crisis. Moreover, an adverse distributional effect of banks credit supply is taking place, because only large companies, with better financial conditions, can borrow money (Couppey-Soubeyran 2020). Greater inequality will arise and sum up to the already rising inequality coming from the crisis itself. Still, if economic recovery takes time to happen, increasing households and companies' debts will be a problem. Their revenues will not rise in the short run. From this other channel more inequality is expected, bringing further issues to the future economic recovery.

On the fiscal policy side, States are massively increasing their debt. They borrow on the bond markets aiming at financing emergency measures. Yet, financing losses and shortfalls have not the same multiplier effects as financing public investments. Both are needed, yet public investments to push and back the economic recovery have not taken place. Therefore, better conditions for debt repayment are not being created. They ask for sustained increasing in revenues coming from an 
economic growth where the multiplier effect is in place (Couppey-Soubeyran 2020). Moreover, the bigger stock of private and public debt after the emergency phase "may in turn weaken the effectiveness of recovery measures implemented in the post-pandemic period in fragile economies overburdened by newly created emergency-related debt" (Botta et al. 2020: 241). So, relying on bank credit to boost the real economy is not the only solution, and perhaps not even the best one, though it is the easiest to implement.

Countercyclical fiscal and monetary policies are required to reboot the economy, because they at least partly offset the income loss of households and companies. But their financing modus operandis should be enlarged. Following Galí (2020) and Couppey-Soubeyran (2020) there should be, for a time restricted to the emergency of the pandemic crisis, a direct transfer of money from the central bank to households, companies and national treasuries. ${ }^{10}$ At the same time, a recovery fiscal plan based on public investment and addressing the healthcare and educational systems, the infrastructure sectors and the climate crisis, should be implemented via bonds issued by government to cover public spending. As suggested by Botta et al. (2020), these bonds should be fully monetized and subsequently written off by the $\mathrm{CBs}$, in order to prevent any emergency-related increase in public debt stocks. ${ }^{11}$

The direct transfer of the central bank money mitigates the downfall in private income. Moreover, when adopting these measures, CBs minimize transmission failures of monetary policy, which relays on the behaviour of financial markets, and avoids adverse distributional effects. The power of this policy in boosting the economic activity comes from both the increased spending in the real economy and the improvement in expectations. From all sides, this policy contributes to framing positive conventions.

In addition, by monetizing public spending, the speed of the public debt raising lowers, governments are less exposed to financial market swings, and risk of a perceived debt unsustainability is avoided. The (re)financing of governments through $\mathrm{CB}$ purchases of government debt improves the conditions of public debt markets, controlling treasuries' long-term rates, which strongly compete with pro-

\footnotetext{
${ }^{10}$ On 9 April 2020 the Bank of England opened "a line of credit to the British Treasury to avoid the latter having to go through the bond market. This is not yet monetization in the strict sense of the term, as it is refinancing on the basis of repayable loans, but it is certainly more direct refinancing than that of the Eurozone Member States" (Couppey-Soubeyran 2020: 5).

${ }^{11}$ Botta et al. (2020) propose that governments should take the lead and act via fiscal policy by issuing two sets of bonds in order to finance both the recovery investment plan and the emergency measures. According to them, the latter are related with government bonds that the central bank directly purchases on the primary market and should be backed on the transfer money directly to unemployed, selfemployed and freelance workers as well as for covering around $70.0 \%-80.0 \%$ of all businesses labour costs (up to a predetermined ceiling) and the full amount of fixed costs, with no-layoff clause for employees benefitting from temporary employment protection schemes. On the other hand, the recovery plan should be financed by recovery bonds, aiming at financing the medium-to long-term economic recovery.
} 
ductive investments. Financial markets are too unstable due to the crisis and they may impose difficulties for the government's debt roll over, such as charging higher interest rates because of the perceived greater risk of a raising debt in a moment that governments necessarily have to increase public debt to address the manifold effects of the pandemic. Furthermore, the risk of financing the emergency measures only by means of increasing public debt, mainly in the post crisis period, "will force the country to adopt fiscal austerity and experience low growth rates for many years." (Bresser-Pereira, 2020: 244).

But there are some more arguments in favor of using CBs' money and public debt to finance the economic policies undertaken to tackle the economic effects of the Covid-19 pandemic. These benefits come from the recall of Keynes's writings. In the Post-Keynesian literature, the MMT states extensively about the use of public debt and money issuance to execute Lerner's (1943) functional finance (Terra 2019) (Colander 2002, 2014) (Wray 2014). Still, in the following two subsections we base these new arguments on the above described Keynes's views.

\section{Effects of money creation}

Although monetizing public spending are often criticized by mainstream economists because of potential inflationary effects, or even a collapse in the value of the currency, this is not quite so true to the Post-Keynesian perspective. Demand and expectations are the channels through which issuing money may bring up inflationary pressures. Concerning to the demand channel, orthodox economics assumes a stable velocity of circulation of money as well as full (or natural) level of employment. However, these assumptions do not survive in the presence of fundamental uncertainty. ${ }^{12}$

The increase in uncertainty because of the crisis raises liquidity preference causing money velocity of circulation to fall. In this case, the creation of money does not boost aggregate demand; indeed, it tries to avoid a deep economic slump and, thus, the prices remain stable. Furthermore, even if for some reason hoarding money does not change money's velocity of circulation, an increasing demand does not necessarily generate inflation. This is the case only when there is a low idle capacity in the economy. Still, in this case, the demand rise stimulates investment plans, increasing supply capacity along with a greater employment and aggregate income. Still, in this case, some measures should be taken to coordinate demand and supply, mostly by creating incentives to enhance the countries' productivity, what only happens when there is ongoing demand. Public demand can be reduced in times of private sector boom, but it should never be deliberately depressed.

\footnotetext{
12 Orthodox economics also assumes the exogeneity of money and the causality relation runs from money to prices. However, in the Keynesian view, money supply is endogenous and, according to BresserPereira (2020), it does not cause or accelerate inflation, quite the opposite, money supply grows to catch up increasing prices.
} 
For instance, between 2008 and 2019, the United States, the Eurozone, Japan and China issued together more than US\$ 15.0 trillion. There was no price instability in these regions, or in the world. There was no financial crisis. There were productivity gains. The reason is: in the aftermath of the Great Financial Crisis, uncertainty increased, and money circulation fell, offsetting the expansionary monetary policy effects on prices but, at the same time, the continuous stimulus gave some track to the economic activity, pushing growth and productivity as well as reducing unemployment.

Regarding the expectations channel of the economics mainstream, it believes that a perceived price raise in the future is anticipated in actual price levels. It is a distributional conflict in which everyone tries to protect their income, culminating in prices going up.

However, to the Post-Keynesian view, there is a web of contracts in the economy aiming to reduce uncertainty. Contracts require a unit of account whose value is stable. In Keynesian literature, money supply is scarce in view of its demand due to its negligible elasticities of production and substitution. Monetary policy takes care of maintaining money's scarcity relative to a constant demand for it, what contributes to the stability of its value. Because it is relatively scarce, and not because it is absolutely scarce as claimed by the mainstream economics, money becomes a unit of account for contracts ensuing its function as a means of exchange. Consequently, money also becomes a reserve of value and bears the maximum liquidity in the economy, exercising its three functions: unit of account, means of payment and reserve of value. At the same time, contracts reinforce the stability of its value, and make prices fairly rigid in the short-term.

However, contracts are not a full guarantee against inflation. The stability of a currency's value is also a social convention (Terra 2019). Agents only lose their faith in money when its supply is bigger relatively to its demand. In this situation, money is disregarded as a mean to protect wealth over time, leading to a rush to purchase goods and other assets, such as real estate and foreign money, which will result in inflation. So, bad conventions concerning the management of money by CBs creates expectations of inflation and in a self-fulfilling prophecy, inflation emerges. Under normal conditions, in which there is no expected or installed recession, uncontrolled creation of money, that is, a supply of money that break down the principle of negligible elasticities of production and substitution of money, may stimulate inflation instead of economic growth. Within a recession, money creation helps to lower interest rates as well as reduces the risk agents perceive and that makes them hoard money. If they interest object, money, is reached more easily, their liquidity preference may soften.

By the way, this perhaps is the main criticism of MMT. It defends the absence of restrictions to the government spending in its own currency; only supply and political restrictions matter. Tymoigne and Wray (2013) recognize the presence, in an economy that has not yet reached full employment, of what Keynes called semiinflation in Chapter 21 of his GT; i.e., increased demand drives up prices in those sectors with an elasticity of output below one. Moreover, Tymoigne and Wray 
(2013: 48) comment that "normally, as Keynes said, a rise of effective demand 'spends itself, partly in affecting output and partly in affecting price'." Apart from that, public finances should function to reach full employment and any type of State liability can be used limitless for that, either money issuing or public debt (Wray 1998; Tymoigne and Wray 2013; Wray 2014). However, these authors seem to disregard the mentioned role of conventions for price stability in monetary economies. Other criticism of MMT comes from Bresser-Pereira (2020), who points out the exchange rate constraint to public expenditures based on the New Developmentalism Theory. According to him (2020: 254), "fiscal indiscipline seriously harms a country's monetary competitiveness" and may lead to a currency crisis, because excessively government spending leads to the accumulation of current account deficits if, on the one hand, public expenses make demand grows faster than aggregate supply, and, on the other hand, agents ask for higher interest rates because of the perceived risk of a fast-growing public debt that, as a result, may cause an overvalued exchange rate. The latter, in addition, mitigates the rate of profit and private investment. ${ }^{13}$

Different from the believe of economics mainstream, the Post-Keynesian view is that in the current crisis recession itself anchors prices, either through the channel of expectations (low inflation convention) or because money is hoarded and so the velocity of its circulation falls. So, supply constraints do not exist, the output level is far from the full employment. In these times of crisis, inflation is not unequivocally linked to the amount of money that CBs issue. Therefore, monetizing public spending to finance emergency measures does not cause inflation - it may not cause inflation even when the economy is under normal activity. If the exchange rate becomes too unstable as a consequence of money creation, the problem may be mitigated by the adoption of capital controls (Resende and Terra 2017). In times of exception, exceptional measures are required.

Even after the recovery of the economy, the money created should not cause inflation. At the beginning of the economic recovery the output level will be far from full employment. In this situation, the creation of money should be continued, fostering aggregate demand and mitigating unemployment. As Keynes highlighted in Chapter 21 of his GT, we must first consider the effect of changes in the quantity of money on the effective demand, which depends on changes in the liquidity preference. Moreover, he also pointed out that so long as there are available efficient unemployed resources of every type, issuing money may generates semi-inflation, but not true inflation. The latter occurs when the rise in the prices level is entirely proportional to the monetary expansion. In semi-inflation situation an increase in the quantity of money partly affects output and partly affects prices.

\footnotetext{
${ }^{13}$ Other two criticisms of MMT are the case of emerging economies that (i) cannot borrow in its own currencies, and that (ii) are posited out of the top places in the hierarchy of the international monetary and financial markets. As such they have not gotten the same autonomy to undertake their macroeconomic policies, mainly monetary and the exchange rate policies, as advanced economies have.
} 
Furthermore, in a context of high level of idle capacity and unemployment, a low inflation convention should prevail.

Nonetheless, a supply shock came with the Covid-19 pandemic. Consequently, the recovery of aggregate demand may give rise to an inflationary pressure as time elapses. On the one hand, a needed countercyclical fiscal policy based on physical and digital infrastructures investments contribute to resume the potential GDP, enlarging productivity and keeping inflation under control, like was the case, for instance, in the United States after 2008. On the other hand, some inflation, if occurs, may be positive to lower the burden of the debt inherited from the crisis. Furthermore, central bankers are smart enough to adjust money creation accordingly to inflation. Still, the greatest concern might be now deflation and not inflation.

What is necessary to mitigate the economic meltdown and support the recovery, is just recalibrating the coordination of fiscal and monetary policies, based on increasing the government spending, launching programs to purchase asset from the private sector, and easing liquidity, all based on central banks' money. By the support of money creation, a more aggressive countercyclical fiscal policy, financed by the monetary policy, becomes feasible and more effective as it facilitates public spending without increasing the risk of unsustainable government debt in the long run. A direct transfer of central bank money to national treasuries would enable them to deploy massive public expenditure to manage the health and economic crisis. If inflationary pressures emerge, a reduction in money creation might be replaced by an increasing government debt. It would require a great deal of communication with markets, in order to ensure that this policy arrangement is the best to foster confidence. After all, conventions matter.

\section{Effects of public debt issuance}

A sustainable government debt in the long run matters in the Keynesian perspective. Indeed, Keynes (1980) argued that an unbalanced public budget should be the last option. Likewise, Minsky (1986) pointed out that public budget deficits, if occurs, should be understood as temporary. More important than the level of the public debt-to-GDP ratio, is the market's confidence in its stability. A public debt rise whose convention is deemed as uncontrollable may entail the expectation that government will create money and/or raise taxes to meet its debt commitments in the future. As argued, the monetization of public debt in the absence of an economic recession can destroy the confidence in money and be inflationary. Doubts concerning the raise in taxes (such as, in what magnitude would it be? Upon which productive sectors and layers of society will it be charged?) disrupts confidence in the trail the government is pursuing, increasing uncertainty regarding the future path of the economy and inhibiting investments.

However, confidence in the stability of the public debt-to-GDP ratio no longer exists worldwide currently, since it was undone by the economic crisis originated by the Covid-19 pandemic. However, the negative interest rates in advanced countries, and their minimal levels in emerging economies treasuries' long-term bond, 
denote that public debt is the most required financial asset nowadays, even with countries facing, concomitantly, their highest level of public debt amid current huge public deficits.

Ironically, when markets are in panic and uncertainty grows, it is solely the public debt that offers liquidity, profitability and safety. So, public debt can only grow with decreasing interest rates because $\mathrm{CBs}$ execute quasi-public debt management and investors wish treasury bonds in their portfolios. An increasing debt is rather the will of investors not their last resort option. If this was not true, public debts all over the world would not be growing together with greater government spending.

Thus, in the post-crisis, the public debt-to-GDP ratio will be higher worldwide, but without necessarily producing a loss of confidence in its stability in the long run. This trust is framed by the prevailing convention: if all countries will have their public debt-to-GDP ratio increased, a new shared belief emerge suggesting that higher levels of public debt are the new normal. This does not mean that the aforementioned ratio is necessarily the one that will be seen as normal some decades ahead. But now it is, and it is now that the Covid-19 economic effects must be addressed.

It was estimated by Reinhart and Rogoff (2010) that this level would be $90.0 \%$ for advanced countries. However, as Pescatori et al. (2014) argue, there is no such magic threshold. According to Trading Economics (2020), Japan, Italy, Portugal, Greece, Spain and United States, among others, have debt over GDP at, respectively, $237.0 \%, 135.0 \%, 118.0 \%, 177.0 \%, 95.5 \%$ and $107.0 \%$. Moreover, the Trading Economics (2020) shows that there are developed and emerging countries on this list with a higher debt-to-GDP ratio than $90.0 \%$. But there is not governments debt insolvency crisis.

The public debt-to-GDP ratio dynamics depends both on the GDP growth rate and the interest rate level. The latter will remain very low during the economic recovery, as there will be both high idle capacity level and very low inflation expectations, contributing to public debt solvency. When interest rates start signalling some loss of confidence in the long-run sustainability of the public debt, a progressive tax reform should be carried out, signalling the government's ability to adjust its fiscal budget, contributing to stabilize the public debt-to-GDP ratio and to reduce the social inequalities.

\section{FINAL REMARKS}

First, based on Keynes and Post-Keynesian theory, the article showed how, in modern economies, and, mainly, in a global economy, State and market can cooperate to boost economic activity. The idea was to show that economic policies, managed by fiscal and monetary authorities, can mitigate the uncertainty of the agents' expectations and bring up optimistic convention. As a result, they stimulate the consumption and investment's decisions. 
Second, we briefly presented the modus operandi of the Keynesian economic policies, namely fiscal, monetary and exchange rate policies and their connection to conventions. Thus, it was showed that these policies are important for stabilizing the economy and promoting social development. Third, we evaluated how money creation and public debt are important during periods of economic slump. Given that, it showed that money creation and public debt have to be addressed to mitigate the negative impact of the Covid-19 on the world economy as well as to support its future recovery.

\section{REFERENCES}

Arestis, P., Ferrari F', F., Resende, M. F., Terra, F.H.B. (2019) "Brazilian monetary and fiscal policies from 2011 to 2017: Conventions and crisis”, Challenge: The Magazine of Economic Affairs, 62(3): 187-199.

Aspromourgos, T. (2014) "Keynes, Lerner and the Question of Public Debt", History of Political Economy, 46 (3), pp. 409-433. DOI: 10.1215/0082702-2796209.

Bazili, M., Zapia, C. (2006) Shackle and modern decision Theory. Italy, Department of

Economics, University of Siena, April.

Botta, A., Caverzasi, E., Russo, A. (2020) "Fighting the Covid-19 crisis: debt monetization and EU recovery bonds", Intereconomics: Review of European Economic Policy, v. 55, n. 4, July/August: 239-244.

Carvalho, F.J.C. (2014) Expectativas, Incerteza e Convenções. In: Monteiro Filho, D.C., Prado, L.C.D., Lastres, H.M.M. (Orgs.). Estratégias de Desenvolvimento, Política Industrial e Inovação: ensaios em memória de Fabio Erber. Rio de Janeiro: Banco Nacional de Desenvolvimento Econômico e Social, 235-262.

Carvalho, F. J. C. (2015) "Keynes on expectations, uncertainty and defensive behavior”, Brazilian Keynesian Review, 1(1), May: 44-54.

Colander, D. (1984) “Was Keynes a Keynesian or a Lernerian?”, Journal of Economic Literature, XXII: 1572-1577. Accessed at: https://www.jstor.org/stable/2725382.

Colander, D. (2002) "Functional Finance, New Classic Economics and great great grandsons", Middlebury College Economics Discussion Paper, n. 02-34.

Couppey-Soubeyran, J. (2020) Helicopter money to combat economic depression in the wake of the Covid-19 crisis. Veblen Institute for Economic Reforms, May.

Dequech, D. (2000) "Fundamental uncertainty and ambiguity", Eastern Economic Journal,v. 26, n. 1, Winter 2000: 41.

Dequech, D. (1999) "On some arguments for the rationality of conventional behaviour under uncertainty: concepts, applicability and criticisms, in C. Sardoni, and P. Kriesler, (eds), Keynes, postkeynesianism and political economy. London, UK: Routledge.

Dow, S. C. (2010) Keynes on Knowledge, Expectations and Rationality, Center of Capitalism and Society Conference on Microfoundations for Modern Macroeconomics. New York, USA.

Ferrari-Filho, F. and Conceição, O. A. C. (2005) "The Concept of Uncertainty in Post Keynesian Theory and in Institutional Economics", Journal of Economic Issues, XXXIX (3): 579-594.

Flassbeck, H. (2018) "Exchange rate determination and the flaws of mainstream monetary theory", Brazilian Journal of Political Economy, v. 38, n. 1, January/March.

International Monetary Fund (IMF). (2020) Policy responses to Covid-19. Washington: IMF. Accessed at: https://www.imf.org/en/Topics/imf-and-covid19/Policy-Responses-to-COVID-19

Keynes, J. M. (2008 [1921]). A Treatise on Probability. Seaside: Rough Draft Printing.

Keynes, J.M. (2007 [1936]) The General Theory of Employment, Interest and Money. London: Palgrave Macmillan. 
Keynes, J. M. (1980) Activities 1940-1944: shaping the post-war world - The Clearing Union. The Collected Writings of John Maynard Keynes, XXV. Londres: Royal Economic Society/Macmillan.

Keynes, J. M. (2010) Essays on persuasion. The Collected Writings of John Maynard Keynes, X. Londres: Royal Economic Society/Macmillan.

Lerner, A. (1943) "Functional Finance and the Federal Debt. Social Research", 10(1): 38-51.

Minsky, H. (1986) Stabilizing an unstable economy. New Haven: XXI Century Fund Report.

Modenesi, A. M., Modenesi, R. L. and Martions, N. M. (2012) Convention, Interest Rates and Monetary Policy: a post-Keynesian-French-conventions-school approach. Rio de Janeiro, Brazil: VII Encontro Internacional da Associação Keynesiana Brasileira.

Pescatore, A., Sandri, D., and Simon, J. (2014) "No Magic Threshold”, International Monetary Fund Finance \& Development, 51 (2): 39-42.

Plihon, D. (1995) “A ascensão das finanças especulativas”, Economia e Sociedade, (5): 61-78.

Reinhart, C. M., Rogoff, K. S. (2010) "Growth in a time of debt", American Economic Review, 100 (2): 573-78.

Sen, S. (2018) “Investment decisions under uncertainty", Levy Economics Institute of Bard College. Working Paper n. 918, December.

Shackle, G. L. S. (1979) Imagination and the nature of choice. Edimburgo: Edinburgh University Press. Skidelsky, R. (2010) Keynes: the return of the master. London, Penguin Books.

Terra, F. H. B. (2019) A política fiscal na perspectiva Pós-Keynesiana. In Feijó, C.; Araujo, E.C. (orgs) Macroeconomia Moderna: lições de Keynes para economias em desenvolvimento. Rio de Janeiro, Elsevier: 57-68.

Trading Economics (2020) Accessed in 30 July 2020 at: https://pt.tradingeconomics.com/country-list/ government-debt-to-gdp

Tymoigne, E.; Wray, L.R. (2013) “Modern Money Theory: a reply to critics”, Working Paper n. 778, Levy Economics Institute.

Wray, R. (1998) Understanding Modern Money: The Key to Full Employment and Price Stability, Edward Elgar.

Wray, R. (2014) "From the State theory of money to Modern Money Theory: as alternative to economic orthodoxy", Working Paper n. 792, Levy Economics Institute, March. 